Article

\title{
The Fantasy of the Grand Inga Hydroelectric Project on the River Congo
}

\author{
Jeroen Warner*, Sarunas Jomantas, Eliot Jones, Md. Sazzad Ansari and Lotje de Vries
}

Sociology of Development and Change, Social Sciences Group, Wageningen University, 6706KN Wageningen, The Netherlands; sha.jomantas@gmail.com (S.J.); eliotandpipe@gmail.com (E.J.);

sazzad.ans@gmail.com (M.S.A.); lotje.devries@wur.nl (L.d.V.)

* Correspondence: jeroen.warner@wur.nl or jeroenwarner@gmail.com

Received: 5 May 2018; Accepted: 3 January 2019; Published: 26 February 2019

\begin{abstract}
The Congo River is the deepest in the world and second-longest in Africa. Harnessing its full hydropower potential has been an ongoing development dream of the Democratic Republic of Congo (DRC) and its more powerful regional allies. If completed, the Grand Inga complex near Kinshasa, the capital of the DRC, will be the largest dam project in the world. Its eight separate dams (Inga 1-8) are envisioned to be "lighting up and powering Africa". Opponents claim, however, that the rewards will be outsourced to corporate mining interests rather than meeting the needs of the local population, and that the project is flawed economically, socially and environmentally. The planned construction of the Inga dams and associated infrastructure has been stuck in limbo since it was mooted in the 1960s; a fantasy rather than a reality. This article attempts to analyse the rivalry underlying the Grand Inga scheme beyond the "pro" and "contra" reports. Embracing Lacanian psychoanalysis and triangulating multiple sources, we seek to unmask Grand Inga as a potent fantasy. Whilst exhibiting its purpose to serve as a screen to protect both proponents of and opponents to the dam from encountering their own self-deception, we conclude the scheme to be at its most powerful whilst the dream remains unfulfilled.
\end{abstract}

Keywords: Jacques Lacan; psychoanalysis; fantasy; mega-dam; Inga; DR Congo; hydropolitics

\section{Introduction}

The Grand Inga Project is the largest, most powerful and possibly most controversial prospective hydroelectric dam development project ever imagined. It is the flagship of the Democratic Republic of the Congo's (DRC) development strategy, a proposal of overwhelming prestige which has captured global imagination since the 1960s [1]. Despite receiving considerable support from leading financial institutions, however, it has, so far, not been built. In 2017, the Grand Inga project made the headlines when the World Bank (WB) declared it was going withdraw its support from the project, citing a lack of transparency and failure to observe international good practices as major causes [2]. Despite the failure of the original Inga dams 1 and 2, a World Commission on Dams (WCD) report deeming mega-dams economically and environmentally unviable [3] and left without its major investor, the Inga dream pushes on. In October of 2018, the DRC signed off on a deal with two international private companies to outsource the construction in return for mining rights [4]. Bruno Kapandji, DRC's Minister of Electricity and head of the Inga development and promotion agency, ADEPI, even states that "as Congolese we have no choice but to build Inga 3" [5]. In this article we venture to question why the dream perseveres and has done so for such a long time in the face of considerable setbacks.

In the early 1990s, the influential field of post-development emerged, represented by authors such as Escobar, Ferguson and Crush, seeking to 'decolonise the imagination' of development from its (Western) preconceptions. It was preoccupied with asking why projects of this nature proceed 
regardless of their persistent failure. It attempted to reconcile the often inherently contradictory realities of international development and political projects [6]. In this field of endeavour an emerging strand of scholars within this post-development domain draw on psychoanalysis to explain why many continue to harbour desires for development. In this line of thought, we postulate that in the case of the dam, it may actually be of more benefit to the DRC as a fantasy than as a possible reality. In doing so, we employ an interpretation of Jacques Lacan's theories on psychoanalysis, an emerging theoretical grounding that looks deeply into the more human, emotional aspects of development [7] and constitutes a linguistic re-interpretation of Sigmund Freud's teachings. Lacan has been adopted in multiple disciplines of social sciences, in response to frameworks that failed to account for the irrational dimension of capitalism and development [8].

Interpreting Lacan's psychoanalytical theory in development studies, as done by scholars such as Kapoor, Sato, de Vries and Fletcher, desire is the ability to 'produce dreams and utopias that are both evoked and betrayed by actual development projects' [7-10]. De Vries' interpretation, we claim, sheds new light on the question of why the Inga 3 dam persists in its state of limbo, and reflects on the relevance and merit of this framework within the context of (capitalist) development. Using Lacanian terminology, we showcase the Grand Inga project as a fantasy, not in the typical definition of the word, but specifically as an imagined entity, formed by an amalgamation of unconscious desires [11]. These desires belong to a variety of actors composed of those "in favour of" the dam in the form of the DRC government and its financial investors, and those "against" including environmental NGOs and academia. The force behind the Grand Inga is proclaimed as the pinnacle of progress, the greatest and best project yet in terms development and sustainability. It departs from traditional contemporary development practice of deliverable small-scale projects [12] and builds upon an enormous drive to achieve major goals. Our argument is, however, that these ideas are so grandiose that they actually work to hinder the project by their own ambition.

\section{Lacan and Development}

The Parisian psychiatrist Jacques Lacan transformed psychoanalysis from an approach to curing neuroses to an analytical instrument to analyse developments in society, a (still controversial) idea that has since widely been taken up in the social sciences (In addition to those already mentioned, these include geography [13], geopolitics [14], ecology [15,16] critique of capitalism [17] and spatial planning [18]). When used in the analysis of post-development, Lacan's logic of the individual is applied to whole populations and even institutions and international organisations.

Here, we will zoom in on the Lacanian Triad, which Lacan, in his final years of writing, came to see as his most applicable analytical tool [19]. He posits that there are three equal orders of consciousness within this Triad; the Real, the Symbolic and the Imaginary. The latter two realms are where we, as humans, generally find our 'reality'; the Symbolic, most evidently expressed in language, is the means by which we apply meaning to the world, the basis of knowledge defining how we come to know ourselves and one another; the Imaginary creates the ego, that which offers the conception of a self as opposed to the other, an individual identity acting apart from the broader collective. This allows people to act in accordance with their own personalised rationale and feelings. The Real is all that resists substantiation in the other two orders forever unattainable and inaccessible and beyond grasp, always escaping signification in the Symbolic $[9,11,19]$. This Triad will be our entry point for discussing the dam.

As humans, we are born into the Real, with no understanding of the world beyond our instinctual needs, which are met by our parents. Lacan recognises two essential stages in a child's development for forming adult consciousness. The first, the mirror phase, occurs when a child is first met with their own reflection and begins to recognise itself as a separate entity from their mother. The second stage is when that child begins to understand and use language as a tool of representation and signification. It is the language that the parent uses to describe the child that defines how it understands itself and comes to structure their entire existence. These phases are the child's introduction to the 
Symbolic and Imaginary orders. They are its most significant influences on becoming an individual but, simultaneously, they create a void, an emptiness within the child's psyche. The separation from the maternal body and the subjection to the 'abstract structure' of words forms in the adult individual, or the 'Subject', an insatiable yearning to find satisfaction in that which cannot be achieved $[9,11]$.

The Subject represents a tension between the lack within and the defined societal order outside. Structured and constituted by society and its rules, the Subject then reproduces such an order by entering into it and being 'filled' with its meaning. This can be any form of ideology, from communism to sustainability [20]. Even if agency for change to the Subject is granted, the Symbolic order in itself never ceases to exist, evolving only to represent new values, practices and rules of engagement. Moving past the libidinal fixations of Lacan's original writings, the same theory can be then employed to critique economic development [7-9,11].

The work of French philosopher Michel Foucault has offered the grounding theory in development critique for the past two decades [8]. Despite great leaps in the understanding of power within the field, this does not extend to the Real order in developmental discourse. Scholars analysing those offering and receiving development can appeal to the Imaginary and Symbolically defined needs of their subjects, but this risks only reifying the existing rhetoric and repeating actions that have been shown to fail. Recognising the Real order is essential to determine an antagonistic dimension that reproduces and challenges the other two orders.

The void that is created by the tension between the Real and Symbolic, produces in the Subject two fundamental unconscious forces: drive and desire. Post-development scholars, including Ilan Kapoor, have adopted these concepts to explain the apparent satisfaction in failure of development ([7] p. 67). Kapoor differentiates the two processes as follows: 'desire targets a lost object to cover up our lack-an object that is never found' as opposed to drive, the process of finding enjoyment in that lack ([7] p. 69). Within capitalism, the apparent drive is to consume, finding solace from the void in our psyche. Kapoor argues that development practice pursues the very same logic of consumption, preceding capitalism's tendency to reproduce inequalities. Development functions as a trade-off, exchanging the potential for progress for actual access to resources, e.g., mining rights and hydropower. Therefore, we see that while the movement of capital may on the surface appear to be leading toward a more 'developed' world (which is the desire), the drive unconsciously promotes the same structures of hegemonic capital accumulation. This has potentially disastrous future consequences as, rather than pursuing the goals of equality that development purports to promote, it is actually empowering the forces that produced this disparity of wealth in the first place [7].

What Kapoor proposes is the return of human passions in the analysis of development. Rather than looking at the rationale behind what is evidently an irrational phenomenon, pursuing a goal that only exacerbates the problem first addressed, he sees development as a result of an unconscious libidinal force, something innately human and beyond the scope of traditional analytical tools. We argue that the Inga project, the most illustrious vision of international development and its proponents in and around the DRC, is an amalgamation of coinhabiting desires. It is an imagined object promised to alleviate all of the Republic's problems, both Symbolic and Real. Emanating from the work of psychoanalyst Darian Leader, objects of desire have both Real and Symbolic elements [19]. As Lacan writes 'it is the Real which creates ... desire by reproducing in it the relationship between the Subject and the lost object' ([19] p. 724). The 'lost object' in this sense, forces the Subject to cling onto the Imaginary order, providing an identity. Yet the resurfacing of the Real, reminds the Subject of the void within; this unbearable realisation ultimately drives it to seek what Lacan calls jouissance.

Roughly translated as 'enjoyment', jouissance is understood as the insatiable pursuit of a certain goal (desire) despite experiencing both great pleasure (presence) and pain (absence) [9]. Drawing on jouissance, Robert Fletcher maintains that the scourge of overpopulation remains a popular motivation for pursuing development among its propagators, including the WB. The desire in this case, for the world to become 'developed', is pursued (presence/pleasure) even though this premise has been widely shown as false (absence/pain) and, therefore, contradictory of its goal $[9,11]$. Demonstrating 
the irrationality behind development discourse and its presentation in the Symbolic, he shows how the desire for development is deeply rooted in constructing ones jouissance in relation to an 'Other', in this instance, the undeveloped. Developed nations perceive themselves as domesticated and civil in relation to the animalistic and primitive sexual tendencies of so called 'Third-World' nations. They feel threatened by the Others' apparent lack of control in breeding and, therefore, invest much time and energy into solving this issue [9].

This leads to the final concept relevant to this study: fantasy. As Lacan writes 'desire is propped up by a fantasy, at least one foot ... of which is in the Other, and precisely the one that counts, even and above all if it happens to limp' ([11] p. 658). Here Lacan refers to the desires imposed upon the Subject within the Symbolic order; he explains that to engage socially in the world, the subject must conform to its demands. The 'fantasy' Lacan describes is produced by this compulsion to fulfil or to counter the desires that are drawn from the Other. Whereas, when he writes 'if it happens to limp' he confirms that this desire only reminds the Subject of the lack, reproducing the void even in an attempt to hide it. Translating this to capitalist development rhetoric, Kapoor states that there is a need to be 'the best, biggest, tallest, richest, most original ... [covering] everything from coffee and art to national monuments, airports and dams' ([7] p. 71). To be a significant voice in the world of international NGOs, governments and development institutions, each party must in some way play toward ideals embedded within the Symbolic order, both to gain recognition and to feed their drive.

Rather than focusing on those institutions that push top-down development, as do Fletcher and Kapoor, Pieter de Vries addresses how 'to be developed' also has become a fantasy [10]. He shows how the desire of external development agencies, representing here the Lacanian Other, instilled onto a Peruvian indigenous group in the Andes a desire to become 'developed'. By adopting and embodying western bureaucratic elements, the tribe, while bizarre to them, then assumes to be on their right path of 'progress'. The concept of development, argues de Vries [10], produces nothing but a 'desiring machine'-imposing via the Symbolic order undeliverable aspirations upon already impoverished peoples.

This article identifies the Grand Inga project as such a fantasy or 'desiring machine' [10]. Drawing on a broad range of materials, extensive review and triangulation of over 90 journal articles and 40 online sources, our analysis combines three specific readings of the Grand Inga case, each exploring how the dam's persistence in the Symbolic maintains the deadlock. In the first, we present specific groups and individuals and the discursive actions of each, to consider what is produced and what kinds of rhetoric is drawn upon and envisioned. The next step shows, what possible jouissance is pursued, and the role played by the language, presented in the first reading. Finally, in the third step, we investigate the actual repercussions of said fantasy. We investigate what tensions are maintained, and how these both undermine and reproduce the dam as a dream. Before we delve into this in-depth analysis, however, we offer a short review of the history of the Inga dams.

\section{Grand Inga in Context}

Water resources in Africa have bedazzled prospective developers since colonial times, promising extremely inexpensive energy for mining and the export of raw materials. With its $42,000 \mathrm{~m}^{3} / \mathrm{s}$ water flow at the Inga falls (rapids forming part of the Livingstone Falls, see Figure 1 below), the Congo fuelled fantasies of a megaproject as early as the 1930s when technologies of this nature first became available on the African continent [21].

The DRC gained its independence in 1960, five years after the Belgian colonial powers first announced an Inga dam scheme. The then President Mobutu took the project forward and the current President, Kabila, evidently continues to champion it [22]. The country is known for its rich mineral wealth, yet the Fund for Peace's annual Fragile States Index ranked DRC as the 7th most fragile state in 2017 [23]. Its political instability, harsh terrain, poor infrastructure, largely dysfunctional institutions and ongoing violent conflicts in the central and eastern part of the country, have repeatedly caused the development process to falter [24]. The DRC faces a serious political crisis; some 42 million Congolese 
are undernourished [25] and despite the country's plentiful water resources, 75\% of the Congolese population has no access to clean drinking water [26]. The shrinking administration has left public servants and local authorities with hardly any means to operate and salaries are often left unpaid. The relation between public authority and its citizens remains characterized by deep mutual mistrust and democratic deficits [22].

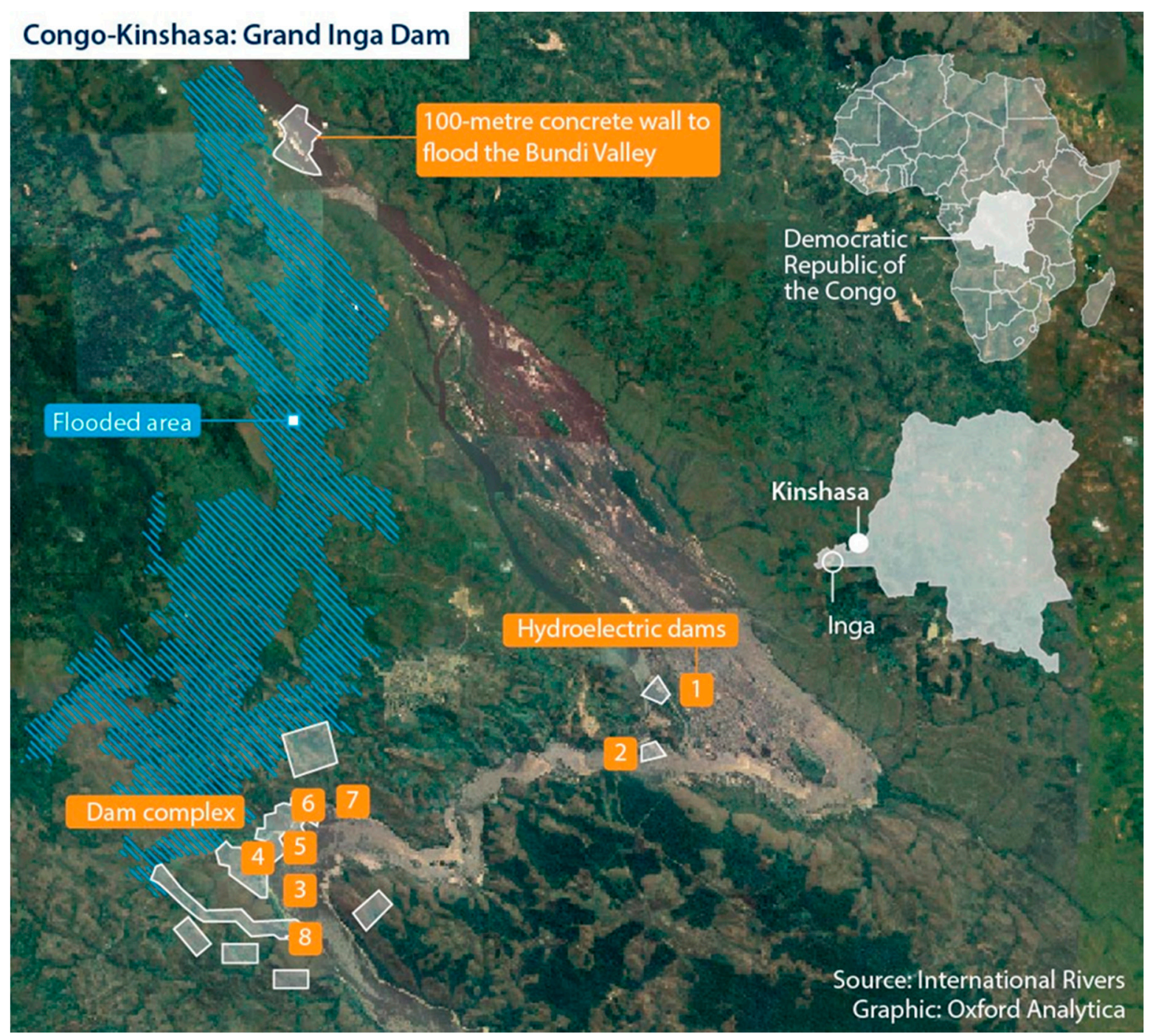

Figure 1. The Inga Valley, the two existing and the six planned dams forming part of the Grand Inga Complex (https:/ / dailybrief.oxan.com/Analysis/GI239798/Congo-Kinshasa-Grand-Inga-dam).

The existing Inga dams 1 and 2 have done very little to alleviate any of this disparity. Constructed in 1972, the first of the two was relatively successful [27]. Completed in only four years, it initially provided a reliable source of energy to Kinshasa and served as a strong success story for promoting Mobutu Sese Soko's emerging dictatorship. The second dam, completed in 1982, however, has not proven so fruitful. It was intended to supply mining endeavours in the east of the country but was built five years before any power grid had been established and was thus useless until this project was completed. During this hiatus the dam fell into disrepair and, due to this poor planning, only $20 \%$ of Inga 2's potential power has ever been utilised. Furthermore, the construction costs of both dams went way over budget, driving the DRC into substantial debt. Albeit, the plan to build a third dam was first conceived in the late 1980s but stalled due to violent conflict in the region $[1,27]$. 
After a slew of controversies over large infrastructural projects in the 1990s (Narmada, Arun, Pergau, Lesotho Highlands and many more) a tripartite World Commission on Dams was instated. In 2000, it concluded that mega-dams, i.e., those over $15 \mathrm{~m}$ high, are unsustainable and cost-ineffective. Yet dams are still popular as purported engines of economic growth and development, albeit under new guises such as climate buffers [28]. According to the Commission [3], 40-80 million people worldwide have been forced off their settlements, agricultural lands, forests and other resources due to dam-related flooding. Over 45,000 large dams have been constructed worldwide and reservoirs inundate approximately $500,000 \mathrm{~km}$ of land surface [3,29]. The adverse impacts of large dams also fall disproportionately on subsistence farmers, indigenous peoples and ethnic minorities, who often rely on common property regimes of resource utilization [30]. Despite this, the pursuit of mega-dams persists.

While the World Bank did not reject the WCD's recommendations, it largely continued along the earlier path [31]. In 2004 the Bank started a two-year project to refurbish the dilapidated Ingas 1 and 2 , with a significant investment of $\$ 200$ million USD [1]. With this new interest in the Congo River, sparked by the UN's Millennium Development Goals, plans concerning Inga 3 began to re-emerge. Some five years later, the WB and WESTCOR (Western Power Corridor) feasibility study concluded that damming the Congo River via a single dam, Inga 3, would inundate and flood the capitals of DRC (Kinshasa) and the Republic of the Congo (Brazzaville). Considering this, a further new project was proposed; the Grand Inga dam Complex, consisting of six separate dams, rather than one [32]. Eleven teams expressed an interest in the construction of the first dam, Inga 3 (GCR1). British aluminum smelter BHP Billiton, one of the frontrunners for the construction of the new Inga, pulled out a year later, without any clear reasons cited [32,33]. In 2012, negotiations were then escalated to presidential level between the DRC and South Africa (SA) [33]; neighbouring countries grew eager to reap a portion of the dam's potential energy.

The resulting Grand Inga Complex is envisioned to be twice the size of the Three Gorges dam in China, currently the biggest hydropower project in the world. It will surmount the great Congo River, the deepest in the world and second-longest in Africa. The African Development Bank (ADB) claims its eight separate dams and associated power stations and transmission network could lead to 'Lighting up and powering Africa' [34].

In 2014, however, the US Congress passed a law forbidding "any loan, grant, strategy or policy ... to support the construction of any large hydroelectric dams" [35] withdrawing support for the WB Technical Assistance (TA) Package of Inga 3. It cited the disappointingly slow rehabilitation of Ingas 1 and 2 and the unsuccessful reformation of the DRC state electrical utility as main causes. Lack of evidence of direct benefits to the local Congolese people, of social safeguards concerning the construction, or of environmental and social impact assessments are also mentioned.

Despite these setbacks, in March of 2014 the WB approved a further \$73 million USD to finance environmental, social and technical studies to proceed with Inga 3. These never took off, however, due to irregularities in the procurement process [36]. The same year, South Korea's Posco and Daewoo, in partnership with Canada's SNC-Lavalin withdrew, leaving Chinese company Sinohydro and Grupos ACS from Spain as the only serious bidders to construct the dams remaining from the initial 11 [37].

By 2016, Inga 1 and 2 rehabilitation programmes were still not finished. 10 years overdue, the projected costs had risen to a staggering $\$ 1$ billion USD, five times the initially predicted figure [38]. Then, to the dismay of the DRC government and the surprise of others, the WB suspended its support for the Inga 3 dam preparations [36]. The Congolese Project Director then, to please his last remaining financiers, proposed to proceed with the dam's construction without environmental, social or technical studies [36]. In June of 2017, the DRC government asked two last bidders to join and submit a single bid to start developing the now long-delayed Inga $3[39,40]$. This bid apparently has been accepted and the Congolese Energy Minister Kapandji bullishly announced construction is to commence this year and to be completed in 2025 [41]. Analysts, however, claim 2030s-2040s is the best possible envisioned date for the remaining five stages of Grand Inga [33]. A grid capable of transferring energy to the Congolese population is yet to be built. 


\section{The Inga Fantasy}

The following analysis is based on Lacan's concepts of drive, desire and his definition of a fantasy [11]. Drive, the process of finding jouissance in the pursuit of an object rather than in the object itself, divides the Subject from their initial intention of obtaining said object. The desire is only sustained by imagining a false relationship between the drive and the object, disavowing the satisfaction found in failure. Lacan writes: 'fantasy is the means by which the Subject maintains himself at the level of his vanishing desire, vanishing inasmuch as the very satisfaction of demand deprives him of his object' ([11] p. 532). Scholars have recognized this phenomenon within development. Japhy Wilson states that large-scale projects such as Grand Inga represent 'development' as a machine, perpetually aiming to improve the lives of those living in the Global South, however, in order to maintain this machine, more and more people need to be considered 'undeveloped' and, therefore, must take its own failure to accomplish its objectives into account in advance [42]. We place Grand Inga within this formulation of failure, showing how Inga as a fantasy feeds the desires of the DRC, the WB and its private investors, on the one hand, and International Rivers (IR) and their scientific backing on the other.

\subsection{The Triad}

Central to the current position of the Grand Inga Project is its Symbolic efficiency [19]. How, why and by whom Inga 3 is discussed allows us a glimpse not only into the various groups and their stakes in the project, but also the intertwined character of different realms pertaining to the Lacanian Triad; the Real, the Symbolic and the Imaginary. The scheme's name alone pulls no punches: 'grand' evokes its impressive size and appearance. It is characterised as stately, majestic, dignified, ambitious, magnificent and noble. The action of describing the dam in such a way feeds its Symbolic potency, furthering its appreciation of the Other, how far it is removed from the Real. As its only signification in the Real is its absence, the dam project can remain unchallenged in this regard. Compared with other, smaller dams, the exaggerated size, the river it aims to tame and the required investment, ranging between $\$ 12$ billion and $\$ 14$ billion USD, Inga puts all other projects to shame [37,38]. In brief, the scheme is in a league of its own [43]. These claims bear little relation to reality beyond the actual size and scope of the Congo River. A brief look at previous attempts to achieve major projects in the region provides significant reason not to believe in the efficacy of such claims. Within the worlds of international development, finance and political relations, however, these may carry a lot of weight. The prestige, excitement and promotion brought to the Congolese government by these plans, a renowned corrupted dictatorship, is extraordinary.

Claims that the hydropower of Grand Inga could supply Egypt via the Sahara, stretching to Europe [44] are very potent. Presented in such Symbolic light, it resurrects hope and support for Grand Inga after two previous failures. This works perfectly for the benefit of both the WB and the ADB, who in lending money to the project also prop up Inga as a driver for regional cooperation [45] —another symbolically positive connotation. The dam, however, is merely an absent proposition, promising to turn the DRC from a third-world economy into a global exporter of 'clean' energy, with little to no evidence.

Through Inga, the DRC likewise projects itself as the new hub for Pan-Africanism, an age-old rallying cry focused on uniting the African continent under one banner [46]. Emerging as a response to the oppression and exploitation African people suffered under colonialism and the slave trade, this movement is a highly potent ideology among continental statesmen. With the DRC geographically at its center, it is already in a great position to take on this role. Cooperation by delivering renewable energy to all its neighbours could also promote the DRC as an emerging authority amongst other regional nation states. As such, Inga has attracted much attention from SA, the current regional leader. The DRC has proclaimed itself to the Western world at large as a progressive and environmentally conscious new African power [47]. This has been validated by the huge support coming from the Congo's regional competitors as they have prepared to invest heavily in the prospective project [48]. 
It seems paradoxical, however, that a country deemed the world's 7th most fragile state [23], which has been in the same perilous political situation for the last 70 years, could become the new face of African solidarity. The Symbolic efficiency attributed to the dam within the discursive sphere of International Relations and development (big, clean, sustainable) has obfuscated its presence in the Real to such an extent that the DRC's poor reputation can be condoned. Using the Triad, we can see how Imaginary identities and social collectives (DRC, SA, WB) cling to their Symbolic rhetoric to remain relevant and important. They project themselves in congruence with the desire of the Other, maintaining a cognitive shield between themselves and their grounding in the Real.

A similar knowledge dispute is reflected by those opposing the dam, where groups use the same terminology to represent contradictory points of view. Many NGOs standing against its construction claim to represent the interest of the environment. They posit that the natural and human cost of building the dam far outweighs its prospective benefits, flooding vast amounts of land where people currently reside [27]. They are supported by much of the scientific community and the WCD report which, as noted, agreed that such projects tend to be neither sustainable nor cost-effective. This same rhetoric, however, is used to promote the dam. The DRC maintains that the dam will provide 'clean' energy and lead to a more environmentally sustainable future for Africa. Bruno Kapandji has insisted that environmentalists are "fabricating" stories in regards to the damaging impacts of the dam [1]. The WB and other parties are working in line with UN sustainable development goals, putting the DRC at the forefront of climate adaptation.

Further contradictions in the Symbolic battle of Inga 3 undermine many of the DRCs promises. While claiming humanitarian goals, bringing energy to the poor and deprived, most of the energy that Inga 1 and 2 produce, is absorbed by mining companies in the eastern Katanga province [1]. In addition, SA, as a key contributor, is assured to be the first and largest recipient of Inga's energy [49].

One would expect that the WB's financial withdrawal might have endangered the whole Inga project. In response, however, the DRC has promised to end their commitment to proper environmental testing, seeking that the private financial interest in pursuit of constructing the dams remains [38]. The actions of those for and against the dam, however, exhibits the power behind the development discourse as the project can survive such a blow. The WB has invested at the very least \$273 million USD into Inga 1, 2 and 3 over the past ten years and has seen almost zero return [2]. The DRC has managed to keep the dream alive despite losing the support of the largest and most respected development financier on the planet due to its own poor planning. These actions can be explained further when considering how these desires function, but first we shall delve into the enjoyment gained, linking the Symbolic value of each group through jouissance.

\subsection{Jouissance}

Jouissance is born of the Symbolic order; it structures desires and future goals, feeding the drive to continue. The semblance of jouissance expected, however, is not the substance of its actualisation (jouissance obtained) $[11,19]$. It would compel the Subject to acknowledge the ugliness and insufficient nature of the object of their desire. Furthermore, such transcendence would make that Subject question the nature of their belief system and self-esteem. The Subject will repeatedly act, consciously or unconsciously, to abide by and conform to the Symbolic order, to reap the rewards of 'jouissance expected'. The deadlock between contested knowledges around Inga 3 manifests itself in buttresses and threats, which each party exerts as hindrances in the quest of the other to obtain jouissance.

Among the most vocal opponents to the Grand Inga project is IR, an activist non-profit non-governmental, environmental and human rights organization. IR questions the development claims attached to dam-building projects and aims to protect rivers while defending rights of dependent communities. IR continuously reaffirms its opposition to the Grand Inga project [50]. As a values-based organisation, its figures are often disputed but IR's critiques resonate in policy circles. Other vocal opponents include Friends of the Earth and African human rights organisations. 
While their discourses reject dam construction, the case for their jouissance, their financial support, media attention and international success requires that other actors and discourses-the financial and governmental stakeholders it sets out to oppose-to pursue the Inga fantasy [31]. Lacan writes: 'my formula for fantasy allows us to bring out the fact that the subject here makes himself the instrument of the Other's jouissance' ([11] p. 697). We may see, by referring to the previously laid out debate over the sustainability of the dam, that each party, by contesting their opponent's Symbolic value, defines their struggle. Each creates the demands the other side must pursue to find jouissance. Its existence, therefore, is premised on this rivalry and is equally culpable for the maintenance of the Inga fantasy. What unites every party within this dispute, aside from the collective fantasy, is the obedience to the symbolic order and the fruits provided thereby.

Here we see different parties, the government of the DRC, the WB, the WCD and IR, claim the same discourse to represent their cause and garner funding and support. While both proponents and opponents present evidence and truth claims, the underlying Symbolic function means that neither can be wholly substantiated in the Real, and the argument is mooted. Both cases can cast doubt upon the other and, therefore, both can manipulate language to best present themselves. In opposition to the previous case, figures regarding the DRCs poor governance record can be ignored because it is assumed that Inga is a solution. Acknowledging this inefficacy, however, would undermine the cause for development and is shunned. This rivalry retains precedence as it serves to increase each party's Symbolic potency, which we will return to in the following reading.

\subsection{Desire and the Fruits of Fantasy}

The object of jouissance, the desire within the DRC's leadership, is to build the dam and reap its Symbolic rewards. The Grand Inga is perceived by the Congolese government and purveyed to its people as a saviour to end all problems, from guerrilla fighting to economic and political upheaval. It will project the country into an important role in political relations and classify it as a 'developed' nation [5]. The exact notion that this is the object of their desire, however, contradicts its potential.

Desire functions by finding a lack in the Other. Therefore, while desire belongs to the Subject, it is vitally socially constructed within the Other. It can only be fulfilled by utterly appeasing the Other, which, according to Lacan, is not possible for extended periods of time, as he or she also has their own insatiable desires $[11,19]$.

In this manifestation, then, the WB recognises a lack of wealth and poverty in the DRC. It is the Bank's desire that the country become 'developed' according to their conceptualisation and agenda. It is fundamental, however, that to regulate their jouissance, and to continue to maintain their relevance and Symbolic power, they must not succeed in this goal. Therefore, they unconsciously disavow their inadequacy by continuing to hold the fantasy of Grand Inga in such high regard. In doing so, the broader development drive may remain intact. After the WB has withdrawn support, the DRC can continue to push for the project to satisfy their own destitution and the WB can drop the project, having exhausted huge resources without repercussion since this may be blamed on the Congolese. In addition, the DRC can realign and push forward their Symbolic cause as an oppressed nation seeking development despite the rejection of worldly institutions $[5,38]$. In this rendering, the WB is the doting financier pushing for development but not succeeding because of corrupt politicians in donor countries [2]. While these stories are somewhat contradictory, their desire does not only survive but is perhaps even strengthened by failure.

It is noteworthy here to remind the reader that this is not the first time that the WB has undergone such a reversal. In 1993, after years of support for the Narmada dam project in India, the WB pulled out due to mounting environmental controversy [51]. This piece of evidence sheds light upon the decades of contestation the WB has undergone regarding mega-dams and its repeated support despite consistent, complimentary problems. An almost identical loan to that offered to the DRC was withdrawn over 20 years previously for the same reasons as Inga, yet the fantasy obfuscates this Real connection. The desire to harness the promises of the Congolese dam shield its unfeasibility right up 
until the moment that the WB must come to terms with the hopelessness of its goal, finally letting go in order to maintain its jouissance.

The DRC has played toward this 'lack' in the international push for development. If a fantasy is that which moves further as one tries to capture it, the DRC in its pursuit of the Inga fantasy has fed the desires of first the WB and SA, and now China, but severely contradicted itself in the process $[1,38]$. SA has become a leader of sorts in the region. Its involvement across the continent is unparalleled to any other African nation, from railway to airport and gas pipeline projects, up to involvement in transboundary river basin governance $[48,52]$. Driven to challenge SA's hegemony in the region, the DRC is seeking international prestige of its own. Inga could potentially grant this shift in power, promising to extend energy supply all the way to Europe [53]. The DRC, however, has also made promises to SA in the form of energy prospects and construction contracts which contradict these assurances. As a leading financier, the DRC must comply with their demands in order to achieve its goals. SA on the other hand continues to exercise its power over DRC, disavowing side deals, expecting up to half of the energy from Inga 3 alone. By assisting the DRC, it is showing its gracious generosity to its developing neighbour. In the trade balance across the Southern African regional development community, SADC, the balance of payments favours SA ten-to-one [33].

The void left by the Bank was soon filled. When the WB pulled out, the Chinese, the next big player on the continent, particularly in the case of dam projects, stepped in [53]. China started to promote overseas investments, exports and contracts to engineering projects outside of China from 2001 onward [54]. Pursuing their resources-for-infrastructure "development" policies, which are often based on build-own-produce norms, free of taxation, China not only builds dozens of overseas dams, but also uses the energy to mine tax-free local resources as part of the package. China's investments in Africa between 2003 and 2015 were \$27 billion USD [55], whereas loans between 2000 up to 2017 totaled $\$ 143$ billion USD. In the DRC alone, its financial injections and commitments have added up to $\$ 9$ billion USD [56]. In return, the Congo will cede the majority rights in a joint venture to develop copper and cobalt concessions in the region of Katanga, to which energy is crucial.

Here we see an old form of imperial domination and colonialism across Africa giving way to a new form of fiscal hegemony, as described by Kapoor [7]. African states continuously look out for investment and aid, they encourage corporate invasion, to materialize and capitalize on resources to their benefit. These rich resources have then been noted to be 'cursing' DRC, laying the foundations for conflicts and continuing violence across its eastern regions [57]. Therefore, by appealing to development, the DRC has invited violent forces into the country, impeding the development process. The desire for international prestige, a reputation for sustainability, peace and prosperity in the DRC, to be found in the construction of Grand Inga, in actuality seem to be escalating problems. Attempts to gain independence might lead to greater economic subordination, particularly in the case of SA. By turning to the Chinese, the DRC must promise much of its resources away, potentially leading to further conflict.

In addition, by dissuading the WB from supporting the project, dam opponents turned it into an even greater environmental threat. Until recently, Sinohydro was on the World Bank's blacklist because of poor compliance with environmental norms [58]. In 2016, the company claimed it could achieve the landmark project in only four years, if they were "free to do whatever they want to" [38], a demand President Kabila has appeased. In their agreement, the DRC has pledged more of its mining reserves. As a consequence, the Chinese will use the dam's clean energy to engage in environmentally degrading practices.

\section{Conclusions}

In each of the cases outlined above, we have shown how desire for an object is sustained, first, by jouissance and, second, that object being projected as a fantasy. Jouissance is found in the pursuit of unattainable goals, reaping Symbolic rewards without actually having to achieve them. Fantasy then asserts that those desires and goals have a potential manifestation and can realistically be achieved. 
This belief, however, is imaginary and mistaken; as Lacan writes, a 'misrecognition' between the drive and the object ([11] p. 724).

The potency of the Grand Inga fantasy is then revealed when considering its ability to support existing regimes of Symbolic power. In other words, the fantasy of Inga 3 instills agency and legitimacy to various groups working both for and against it. Its powerful image projects the possibility of solving the persisting problems for the DRC and the African continent. On the other hand, engaging with this Congolese dream, IR contests the Grand Inga project as a means to promote environmental superiority over economic development. We have shown how, by embracing symbolic interpretation of the dam, IR reproduces the fantasy and secures its position to contest it. The tension between the two sides could be then mediated by private development and construction companies. It seems, however, that they hinge predominantly upon ulterior capitalist interest, rather than the ethical goals they refute.

The Imaginary that precedes and exists within the social construction of the yet immaterial Grand Inga Complex, that permeates between the government, its corporate backers and international onlookers, continues to profess Grand Inga as a development saviour. As such, it ignores and surpasses the Real social, environmental, and economic drawbacks of such a dream. The Inga fantasy, an amalgamation of a variety of contesting desires and knowledges, disavows that which opposes it, suspending the dam in a limbo-like state, constantly on the cusp of 'vanishing desires' ([11] p. 724).

Acting as what Lacan calls a 'narcissistic mirror', the Inga fantasy reflects only positive elements of the Subject $[19,42]$. The WB can justify its support for corporations that continue to exploit and conduct violence in the Congo as they have attempted to rectify these evils by funding the dam, if ultimately failing. IR won a victory over the WB but now have an even greater opponent in Sinohydro. The prospective Inga 3 and its surrounding projects, therefore, seem to be more useful to its proponents and opponents on the horizon of possibility than as a reality.

In the case of DRC, their desire for the dam is sustained by a drive for development, yet their efforts to pursue it only seem to contradict their intentions, inviting violent corporations into their country. For IR, pushing against the dam has only discouraged the more legitimate institutions, such as the WB, allowing less environmentally conscious organisations to appear in their wake. We argued, therefore, that the Grand Inga Complex is more powerful as a fantasy than it would be if it became a reality. The rhetoric that pervades the project has far greater potential to satiate each party's enjoyment as a mere idea and has done so for various groups for over 50 years. Given the evidence above, each time the dam inches closer to construction, the desire of each group is impeded, as evidenced by the recent manoeuvres from Sinohydro. When the dam seems further from reach, as in the WB's withdrawal, however, each group's Symbolic power seems inflated.

We do not predict that the dam will not be built, although there is plenty of evidence to suggest so. Rather, we have shown that, even if the dam would be built, the goals and achievements it claims to encourage will not be realised. Furthermore, the current efforts to build the dam, and their undergirding motivations are contradictory, leading to intensification of the problems they first sought to alleviate.

Borrowing a novel approach from Lacanian psychoanalysis, this study has examined and deconstructed the ongoing Grand Inga dam polemic beyond the classical for-and-against assertions. By recognising the irrational, human construction of the controversy that surrounds the project, maintaining its Symbolic status, we may see how each party works in accordance with the next, how, by standing in opposition, each subject regulates the position of his enemy and how, in every victory, forgoing the Other's desire, the subject only damages his own struggle for enjoyment.

The potential application of Lacan's work could be highly productive in conducting research into the representation of dams and other environmentally related development projects. By showing in the case of Grand Inga, that knowledge contestation is of greater significance, we hope to assist those approaching such deadlocks to gain a critical outlook of the underlying force field. 
Author Contributions: The conceptualization and methodology were constructed by authors E.J. and S.J. They were responsible for devising the frame of analysis, employing Lacanian Psychoanalysis. M.S.A. then validated this framework based on his experience with water management. The combined efforts of these three authors culminated in the original draft. Having seen the novelty in the argument, J.W. and L.d.V. proceeded to review and radically edit the draft for publication in close collaboration with E.J. and S.J.

Funding: This research received no external funding.

Acknowledgments: We thank Robert Fletcher and Esha Shah for their feedback to an earlier version of the present article. Any error of fact or interpretation remains the authors' responsibility.

Conflicts of Interest: The authors declare no conflict of interest.

\section{References}

1. Klemm, J. World Bank Pitches Mining to Drive Energy Investment in Africa. Bretton Woods Project. 31 March 2015. Available online: http:/ / www.brettonwoodsproject.org/2015/03/world-bank-pitches-mining-todrive-energy-investment-in-africa/ (accessed on 14 June 2017).

2. Fabricius, P. The World Bank has Suspended Funding for the DRC's Inga 3 Hydropower Scheme. Where Does this Leave the Project? Institute for Security Studies, 2016. Available online: https:/ /issafrica.org/isstoday/inga-dream-again-deferred (accessed on 14 June 2017).

3. World Commission on Dams. Dams and Development: A New Framework for Decision-Making; Earthscan Publications Ltd.: London, UK; Sterling, VA, USA, 2000.

4. Gandhi, D. Africa in the News: DRC Inga Dam Agreement and Somaliland Port Expansion. 2018. Available online: https: / www.brookings.edu/blog/africa-in-focus/2018/10/20/africa-in-the-news-drc-inga-damagreement-and-somaliland-port-expansion/ (accessed on 25 November 2018).

5. Vidal, J. Construction of World's Largest Dams in DR Congo Could Begin within Months. The Guardian. 28 May 2016. Available online: https:/ / www.theguardian.com/environment/2016/may/28/constructionof-worlds-largest-dam-in-dr-congo-could-begin-within-months (accessed on 14 June 2017).

6. Boelens, R.; Shah, E.; Bruins, B. Contested Knowledges: Large Dams and Mega-Hydraulic Development. Water 2019, 11, 416, doi:10.3390/w11030416.

7. Kapoor, I. What “DRIVES" capitalist development? Hum. Geogr. 2015, 8, 66-78.

8. Sato, C. Subjectivity, enjoyment, and development: Preliminary thoughts on a new approach to postdevelopment. Rethink. Marx. 2006, 18, 273-288. [CrossRef]

9. Fletcher, R.; Breitling, J.; Puleo, V. Barbarian Hordes: The overpopulation scapegoat in international development discourse. Third World Q. 2014, 35, 79-99. [CrossRef]

10. De Vries, P. Don't compromise your desire for development! A Lacanian/Deleuzian rethinking of the anti-politics machine. Third World Q. 2007, 28, 25-43. [CrossRef]

11. Lacan, J.; Fink, B. Écrits; W.W. Norton: New York, NY, USA, 2007.

12. PNUD. Republique Democratique du Congo: Rapport national, Energie Durable pour tous a L'horizon 2030. 2013. Available online: http://www.cd.undp.org/content/dam/dem_rep_congo/docs/eenv/UNDP-CDRAPPORT-ENERGIE-DURBALE-POUR-TOUS-HORIZON-2030.pdf (accessed on 14 June 2017).

13. Pile, S. The Body and the City: Psychoanalysis, Space and Subjectivity; Routledge: London, UK, 2013.

14. Bjelic, D.I. Normalizing the Balkans: Geopolitics of Psychoanalysis and Psychiatry; Routledge: London, UK, 2016.

15. Dodds, J. Psychoanalysis and Ecology at the Edge of Chaos: Complexity Theory, Deleuze, Guattari and Psychoanalysis for a Climate in Crisis; Routledge: London, UK, 2012.

16. Robbins, P.; Moore, S.A. Ecological anxiety disorder: Diagnosing the politics of the Anthropocene. Cult. Geogr. 2013, 20, 3-19. [CrossRef]

17. Tomšic, S. The Capitalist Unconscious: Marx and Lacan; Verso: London, UK, 2015.

18. Gunder, M.; Hillier, J. Planning in Ten Words or Less: A Lacanian Entanglement with Spatial Planning; Routledge: London, UK, 2016.

19. Leader, D.; Groves, J. Introducing Lacan, 2nd ed.; Icon Books Ltd.: London, UK, 2014.

20. Žižek, S. The Sublime Object of Ideology; Verso: London, UK, 1989.

21. Jullien, M. Can DR Congo's Inga Dam Project Power Africa? 2013. Available online: https://www.bbc.com/ news/world-africa-24856000 (accessed on 9 October 2018). 
22. Rosen, A. The Origins of War in the DRC. 2013. Available online: https://www.theatlantic.com/ international/archive/2013/06/the-origins-of-war-in-the-drc/277131/ (accessed on 9 October 2018).

23. The Fragile States Index 2017; Messner, J.J. (Ed.) The Fund for Peace: Washington, DC, USA, 2017; Available online: http:/ / fundforpeace.org/fsi/wp-content/uploads/2017/05/951171705-Fragile-StatesIndex-Annual-Report-2017.pdf (accessed on 11 October 2018).

24. Nguh, A. Corruption and Infrastructure Megaprojects in the DR Congo; International Rivers: Oakland, CA, USA, 2013.

25. Sanyanga, R. Right Priorities for Africa's Power Sector: An Evaluation of Dams under the Programme for Infrastructure Development in Africa (PIDA); International Rivers: Washington, DC, USA, 2015; Available online: https:/ / www.internationalrivers.org/sites/default/files/attached-files/pida_report_21_oct_for_ web.pdf (accessed on 4 April 2018).

26. Maupin, A. Energy and Regional Integration: The Grand Inga Project in the DR Congo. In A New Scramble for Africa?: The Rush for Energy Resources in Sub-Saharan Africa; Scholvin, S., Ed.; Routledge: London, UK, 2016.

27. Sanyanga, R. Inga 1 and Inga 2 Dams. 2017. Available online: https://www.internationalrivers.org/ resources/inga-1-and-inga-2-dams-3616 (accessed on 9 October 2018).

28. Warner, J.F.; Mirumachi, N.; Farnum, R.L.; Grandi, M.; Menga, F.; Zeitoun, M. Hydrohegemony 10 years later. WIREs Water 2017, 4, 1042e. [CrossRef]

29. International Commission on Large Dams (ICOLD). World Register of Dams; ICOLD: Paris, France, 1998.

30. Nüsser, M. Political ecology of large dams: A critical review. Petermanns Geogr. Mitt. 2003, 147, $20-27$.

31. Eeten, M.V. Sprookjes in rivierenland: Beleidsverhalen over wateroverlast en dijkversterking. Beleid en Maatschappij 1997, 24, 32-43.

32. Showers, K.B. Beyond mega on a mega continent: Grand Inga on Central Africa's Congo River. In Engineering the Earth: The Impacts of Mega-Engineering Projects; Brunn, S.D., Ed.; Springer: London, UK, 2011; pp. 1651-1679.

33. Gottschalk, K. Hydro-politics and hydro-power: The century-long saga of the Inga project. Can. J. Afr. Stud./Revue Canadienne des Études Africaines 2016, 50, 279-294. [CrossRef]

34. Donati, M. Lighting up and powering Africa. A Priority for African Development Bank. Supply Management, Chartered Institute for Procurement and Supply. 2016. Available online: https://www.cips.org/en/supplymanagement/news/2016/march/lighting-up-and-powering-africa-a-priority-for-african-development-bank/ (accessed on 3 December 2018).

35. Bretton Woods Project. US Congressional Legislation Threatens IMF and World Bank Plans. 2014. Available online: https:/ / www.brettonwoodsproject.org/2014/01/us-congress-threatens-imf-world-bank-plans / (accessed on 9 October 2018).

36. EJAtlas. Inga 3 and Gran Inga Complex Hydropower Project on Congo River, DRC. 2018. Available online: https: / / ejatlas.org/conflict/gran-inga-hydropower-project-on-congo-river-drc (accessed on 9 October 2018).

37. Rogers, D. Chinese Bidder Praised for Speed in DR Congo's Massive Dam Contest. 2016. Available online: http://www.globalconstructionreview.com/news/chinese-bidder-praised-speed-d7r-co7ngosmas7sive/ (accessed on 9 October 2018).

38. Nevin, T. Congo's Grand Inga Plan Faces a Watershed. Business Live. 13 May 2016. Available online: https: / / www.businesslive.co.za/bd/opinion/2016-05-13-congos-grand-inga-plan-faces-a-watershed/ (accessed on 14 June 2017).

39. Reuters. BHP Pull-Out a Problem for Inga 3 Project. 2012. Available online: https://www.reuters.com/ article/bhp-congo-inga-idUSL5E8DF2AZ20120215 (accessed on 9 October 2018).

40. Bruno, S.E. Inga 3 Project: The Two Remaining Candidates Invited to Submit a Common Offer. BusinessWire. 13 June 2017. Available online: https://www.businesswire.com/news/home/20170613006491/en/ (accessed on 15 June 2017).

41. Clowes, W. Congo Plans to Start $\$ 13.9$ Billion Hydropower Project This Year. Bloomberg. 2018. Available online: https: / www.bloomberg.com/news/articles/2018-06-13/congo-plans-to-start-13-9-billion-hydropowerproject-this-year (accessed on 17 Ocotber 2018).

42. Wilson, J. Fantasy machine: Philanthrocapitalism as an ideological formation. Third World Q. 2014, 35, $1144-1161$. [CrossRef] 
43. Van der Zaag, P.; Robinson, P.; Groverman, V. Inga Basse Chute and Mid Size Hydropower Development TA Project Advice on the Adequacy of the Information Underlying Decision Making. 2014. Available online: www.eia.nl/dsu (accessed on 11 October 2018).

44. Mathiason, N. Fury at Plan to Power EU Homes from Congo dam. The Observer/The Guardian. 23 August 2009. Available online: http:/ / www.theguardian.com/world/2009/aug/23/power-eu-congo-dam (accessed on 28 June 2017).

45. AfDB. Multinational Project Appraisal Report for Inga Site Development and Electricity Access Support Project (PASEL). 2013. Available online: https://www.afdb.org/fileadmin/uploads/afdb/Documents/ Project-and-Operations/Multinational_Inga_Site_Development_and_Electricity_Access_Support_Project_ _PASEL___Appraisal_Report1.pdf (accessed on 30 June 2017).

46. James, C.; Kelley, R. A History of Pan-African Revolt; PM Press: Oakland, CA, USA, 2012.

47. Söderbaum, F. Modes of Regional Governance in Africa: Neoliberalism, Sovereignty-Boosting and Shadow Networks. 2004. Available online: Papers.ssrn.com/sol3/papers.cfm?abstract_id=2398949 (accessed on 10 June 2017).

48. Turton, A.R.; Earle, A. Post-apartheid institutional development in selected Southern African international river basins. In Water Institutions: Policies, Performance and Prospects; Gopalakrishnan, C., Tortajada, C., Biswas, A.K., Eds.; Springer: Berlin, Germany, 2005; pp. 154-168.

49. McEwan, C. Spatial processes and politics of renewable energy transition: Land, zones and frictions in South Africa. Political Geogr. 2017, 56, 1-12. [CrossRef]

50. Bosshard, P. The World Bank's Inga 3 Project Goes from Bad to Worse; International Rivers: Oakland, CA, USA, 2014; Available online: https:/ / www.internationalrivers.org/blogs/227/the-world-bank\%E2\%80\%99s-inga3-project-goes-from-bad-to-worse (accessed on 14 June 2017).

51. Wood, J.R. India's Narmada River Dams: Sardar Sarovar under Siege. Asian Surv. 1993, 33, 968-984. [CrossRef]

52. Meissner, R.; Warner, J. Hydro-hegemony or Water Security Community? Collective Action, Cooperation, and Conflict in a Transboundary Security Complex in the SADC region. In Water Governance and Collective Action: Multiscale Challenges; Suhardiman, D., Nicol, A., Mapedza, E., Eds.; Routledge: London, UK, 2018.

53. Hensengerth, O. Chinese hydropower companies and environmental norms in countries of the global South: The involvement of Sinohydro in Ghana's Bui Dam. Environ. Dev. Sustain. 2013, 15, 285-300. [CrossRef]

54. Pamlin, D.; Long, B.J. Rethink: China's Outward Investment Flows; Worldwide Fund for Wildlife: Grand, Switzerland, 2007; Available online: assets.panda.org/downloads/wwf_re_think_chinese_outward_ investment.pdf (accessed on 10 January 2019).

55. SAIS. Chinese FDI Flow to African Countries, China-Africa Research Initiative, School of International and Advanced Studies, Johns Hopkins University. 2018. Available online: http:/ /www.sais-cari.org/s/Upload_ LoanData_v11_October2018.xlsx (accessed on 26 November 2018).

56. Atkins, L.; Brautigam, D.; Chen, Y.; Hwang, J. China-Africa Economic Bulletin \#1: Challenges of and Opportunities from the Commodity Price Slump; China Africa Research Initiative, Johns Hopkins University School of Advanced International Studies: Washington, DC, USA, 2017.

57. Brautigam, D. The Dragon's Gift: The Real Story of China in Africa; Oxford University Press: Oxford, UK, 2009.

58. Nordensvard, J.; Urban, F.; Mang, G. Social innovation and Chinese overseas hydropower dams: The nexus of national social policy and corporate social responsibility. Sustain. Dev. 2015, 23, 245-256. [CrossRef]

(C) 2019 by the authors. Licensee MDPI, Basel, Switzerland. This article is an open access article distributed under the terms and conditions of the Creative Commons Attribution (CC BY) license (http://creativecommons.org/licenses/by/4.0/). 